Article

\title{
Towards the Healthy Community: Residents' Perceptions of Integrating Urban Agriculture into the Old Community Micro-Transformation in Guangzhou, China
}

\author{
Yuan Ma *, Heng Liang, Han Li and Yaping Liao \\ School of Architecture and Urban Planning, Landscape Planning and Ecological Restoration Research Center, \\ Guangdong University of Technology, Guangzhou 510090, China; lh864547026@163.com (H.L.); \\ lilihan925@163.com (H.L.); siren0125@163.com (Y.L.) \\ * Correspondence: mayuan0714@163.com
}

Received: 30 August 2020; Accepted: 1 October 2020; Published: 10 October 2020

\begin{abstract}
In the renewal of old communities, one of the development directions is to improve health and enhance well-being. A healthy community includes four aspects of health, namely, healthy production, healthy lifestyle, healthy environment and ecosystem, and healthy physical and mental states of residents living in the community. Urban agriculture (UA), as a form of the community garden, is a supplementary form for the lack of production function in the urban community. It also has the potential to contribute to sustainable and resilient urban communities. This study focuses on analysing the health benefits of UA and attempts to identify old community residents' attitudes and perceptions towards UA and understand their confusion and worry. The purpose of this study is to promote the healthy and sustainable development of old communities by integrating UA into the micro-transformation of old communities and provide planning and design strategies and community development ideas for the micro-transformation. Surveys were conducted on 10 old communities in Yuexiu district, located in Guangzhou, China. Statistical analysis was conducted using IBM Statistical SPSS version 26 to obtain information on the factor structure of residents' perceptions towards the health benefits of UA. The analysis results showed significant differences between gender groups and the status of children on old community residents' perceptions towards general UA benefits. The main factors accounting for old community residents' perceptions towards the health benefits of UA were environmental health benefits, physical and psychological health benefits, and community health benefits. When developing UA in old communities, co-construction and co-sharing mode, public participation mode, and promotion mode are three important development strategies. Construction location, design style, and seasonal design are also critical for the construction of UA in old communities.
\end{abstract}

Keywords: urban renewal; urban agriculture; healthy community

\section{Introduction}

Rapid urbanization has radically changed the relationship between humans and the settlement environment [1]. Urban renewal originated in the Western countries and had expanded beyond physical changes to include actions aimed at social and economic improvements. It encompasses three generations, which are physical determinism, neighbourhood rehabilitation that emphasizes social problems, and economic revitalization [2,3]. However, with the urban sprawl and change of the settlement environment, urban problems and human diseases [4-7], such as air pollution [8,9], urban heat island [10], obesity $[11,12]$, respiratory diseases $[13,14]$, cardiovascular diseases $[15,16]$, 
and mental diseases [17], are increasing. Health problems and diseases are the result of a complex series of interactions between human factors, including genetics and health behaviour, and the ecosystems in which humans live [18,19]. Western countries in recent years have begun to actively explore how to make cities and communities sustainable, healthy, and beneficial to human beings through urban renewal programmes. Governments, scholars, and experts of urban planning and public health have continued to explore the improvements in health through urban renewal interventions [20]. Urban renewal programmes include large-scale clearance, increased green infrastructure, and commercial and residential area redevelopment [21,22].

China boldly embarked on a journey from a planned economy to a market economy in 1978, and the urban land reforms and housing reforms ushered in the emergence of real estate markets in the late 1980s [23,24]. Since then, large-scale urban renewal programmes have prevailed in cities across the country, like the large-scale clearance programmes in the 1950s and 1960s in the United States [25]. Measures, standards, and rules have been issued and instituted. These programmes focus on improving the built environment of residential areas [26,27]. In 2017, the Ministry of Housing and Urban Rural Development of the People's Republic of China (MOHURD) proposed the transformation of old communities to improve the quality of residents' life, not only the built environment, and to create a new governance structure of co-governance, co-construction, and co-sharing. The old community mainly refers to the residential areas located in the scope of the old urban area, built before 2000 and still in use, wherein residential units and their external environment are old. The construction standards are low, the use functions and supporting facilities are incomplete, outdoor activity spaces are insufficient, and potential safety hazards exist in disrepair and lack of property services, which cannot meet people's normal or higher living needs.

In the renewal of old communities, sustainability is one of the most important concepts on community development, and how to use the resources to meet residents' current needs while ensuring that resources are available for future generations is a key issue [28-30]. The goals of sustainable community development are to increase land production by maximizing resource utilization, to promote resource recycling by utilizing waste, to promote a sustainable lifestyle by changing the community environment to relax the residents' spirit and stabilize their emotions, to improve communication by encouraging every member to participate in community building, and to foster community attachment by holding interactive activities. As western experts and scholars have done in recent years, one of the sustainable development paths of old communities is to improve health and enhance well-being [31,32], which is in line with the goals of community sustainable development (Figure 1).

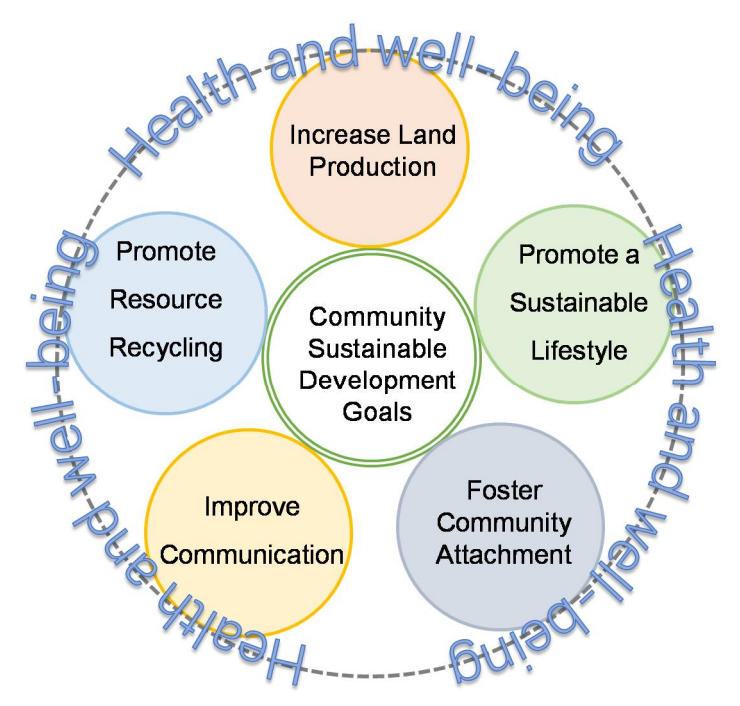

Figure 1. Community sustainable development goals. 
The definition of health was set out by WHO (1946) as follows: 'Health is not merely the absence of disease and infirmity but a state of optimal physical, mental and social well-being' [33,34]. Three changes are needed to turn an old community into a healthy one. The traditional settlement environment is an integrated environment of production, life, and ecology $[35,36]$. However, after agricultural activities being excluded from the city, production activity has become non-existent in the settlement environment, and the ecological function has gradually degraded. Therefore, urban agriculture (UA) is a supplementary form for the lack of production function in the urban community. Except for the provisioning function, UA has been paid more attention by scholars and experts worldwide [37]. Some of them research on the food policies related to UA, whereas others focus on the benefits of UA. UA can contribute to household food security in developing countries and developed counties in times of crisis during the 20th century. However, nowadays, UA is practiced more for social, cultural, and environmental reasons than provisioning [38-40]. The forms of UA are community gardens, urban farms, edible school gardens, and roof farms [41-43]. UA provides people with many nature contact opportunities. Exposure to biodiverse environmental microbiomes contributes positively to human health [44]. UA can re-connect urban populations to biodiverse microbial communities [45-48]. Therefore, UA has been viewed as having the potential to contribute to sustainable and resilient urban communities. UA should not be a substitute for urban green lands, but as a complementary form of green space, which can enrich the types of urban green space [49-51]. Restructuring environments provide opportunities for physical activity and can change the communities' lifestyle [52-54]. Urban planning and design have the potential to impact public health positively or negatively. Changes to the built environment can improve public health through increased opportunities for healthy behaviours [55].

A healthy community includes four aspects of health (Table 1, Figure 2), namely, healthy production, healthy lifestyle, healthy environment and ecosystem, and healthy physical and mental states of residents living in the community. Healthy production refers to a community with healthy built environment and healthy production activities, which can provide healthy food and circulate material resources, such as kitchen waste [38,56]. A healthy lifestyle includes the mental and physical health of people and is related to diverse outdoor activities, all-age participating opportunities, communication promotion, and parent-child relationship establishment. A healthy ecosystem refers to an enjoyable environment, environmental biodiversity, and ecosystem service provision. Old communities usually have no production function, poor environment, lack of outdoor space, lack of available types of activities, and low biodiversity of green space $[37,57,58]$. UA has three beneficial features of society, culture, and environment, and, as such, it is the best strategy that can supply the choice to maintain the sustainable development of a city $[37,59,60]$. The intervention of UA in a community can make the community have production function, improve biodiversity, increase the type and time of outdoor activities of residents, and promote the interaction of community residents. Therefore, UA can make an old community healthy and sustainable.

UA is widely used in communities in European and North American countries [43,61-63]. It has been tried in many old communities in China [64,65]. However, Guangzhou, as the only first-tier city among the 15 pilot cities for micro-transformation [66,67], has carried out significant community micro-transformation so far. However, the integration of UA into the community is relatively rare.

This study attempts to explore the feasibility of integrating UA into the old communities in Guangzhou based on analysing the benefits of UA and the transformation process of old communities in Guangzhou, and to identify old community residents' attitudes and perceptions of UA and understand their confusion and worry. Then, planning and design strategies and community development ideas for the micro-transformation of old communities were provided. 
Table 1. Relationship between a healthy community and urban agriculture (UA).

\begin{tabular}{ccc}
\hline Healthy Communities & UA Activities \\
\hline \multirow{2}{*}{ Healthy environment and ecosystem } & Enjoyable environment & $\begin{array}{c}\text { Create a pleasant environment } \\
\text { through productive landscape }\end{array}$ \\
\cline { 2 - 3 } & $\begin{array}{c}\text { Environmental biodiversity and } \\
\text { ecosystem service provision }\end{array}$ & $\begin{array}{c}\text { Increase plant species and } \\
\text { communities, build animal habitat }\end{array}$ \\
\cline { 2 - 3 } Healthy lifestyle & Abundant green space & $\begin{array}{c}\text { Enrich green space types by } \\
\text { planting productive landscape }\end{array}$ \\
\cline { 2 - 3 } & Experience of farming life & $\begin{array}{c}\text { Planting, cultivation, maintenance, } \\
\text { harvesting, and processing }\end{array}$ \\
\cline { 2 - 3 } & Traditional rural emotional \\
sustenance & Communication promotion & Agricultural education \\
\cline { 2 - 3 } Healthy production & All-age participating & $\begin{array}{c}\text { Co-construction and sharing, } \\
\text { Changing social patterns } \\
\text { Establish a } \\
\text { parent-child relationship }\end{array}$ \\
\cline { 2 - 3 } & Food security & Almost all activities \\
\hline & Waste utilization & Provide fresh vegetables and fruits \\
\hline
\end{tabular}

\begin{tabular}{|c|c|c|}
\hline $\begin{array}{l}\text { Old } \\
\text { Community }\end{array}$ & $\begin{array}{c}\text { Urban } \\
\text { Agriculture }\end{array}$ & $\begin{array}{l}\text { Healthy } \\
\text { Community }\end{array}$ \\
\hline No production & Food security & Healthy production \\
\hline Poor environment & Social benefits & Healthy lifestyle \\
\hline Physical activity & Cultural benefits & Healthy environment \\
\hline insufficient & Environmental & and ecosystem \\
\hline Low biodiversity & benefits & Healthy physical and \\
\hline$\ldots$ & $\ldots$ & mental states \\
\hline
\end{tabular}

Figure 2. Turn old communities into healthy communities through urban agriculture.

\section{Research Design}

\subsection{Study Area}

The study was conducted in Guangzhou, Guangdong Province, China. Guangzhou is located in the centre of Guangdong province, which is one of the most important metropolitan areas in the country (Figure 3). Guangzhou belongs to the subtropical monsoon climate, and has been affectionately called the 'Flower City' since ancient times. The total area is around $7434.4 \mathrm{~km}^{2}$ with a population of approximately 14.04 million people in 2018 (Population, 2018). Guangzhou City governs eleven districts, namely Liwan, Yuexiu, Haizhu, Tianhe, Baiyun, Huangpu, Panyu, Huadu, Nansha, Conghua, and Zengcheng Districts. 


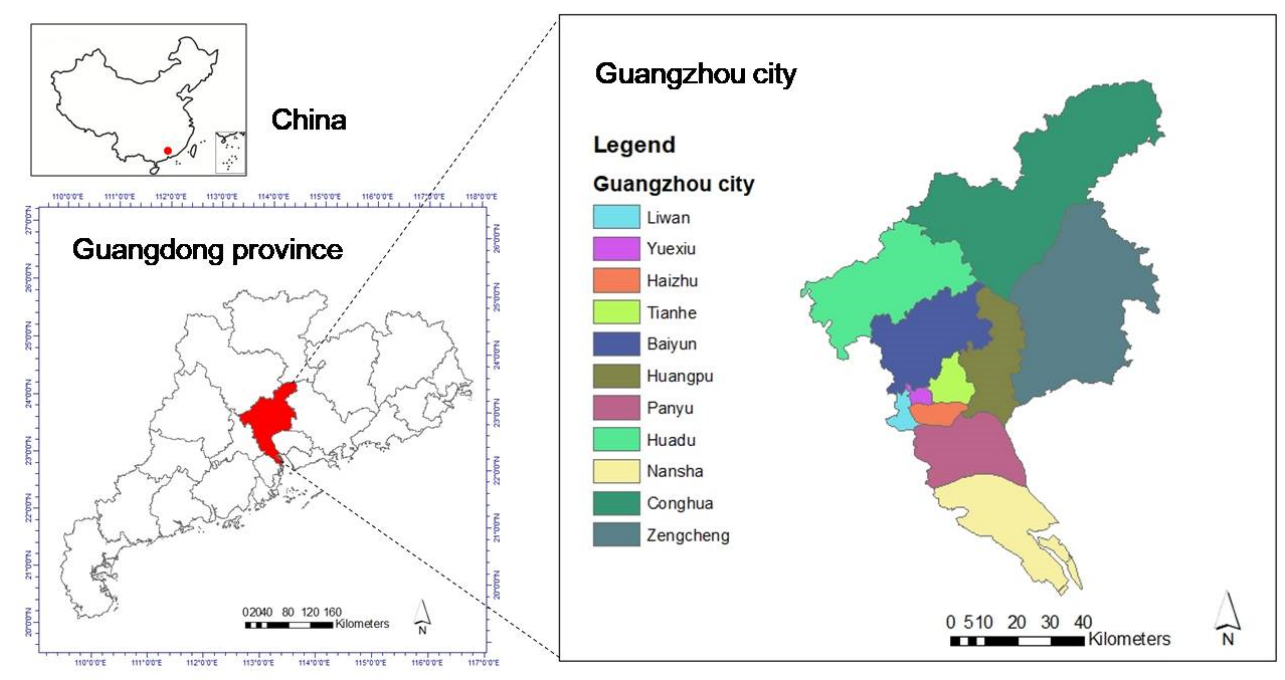

Figure 3. Study area: Guangzhou city.

\subsection{Methods}

This study was conducted with a mixed method of qualitative analysis and quantitative analysis. Literature review, comparative analysis, and inductive analysis were used in qualitative analysis, which was used to explore the relationship between healthy development of old communities and UA, and to analyse the feasibility of integrating UA into the micro-transformation of old communities. The quantitative analysis of this study was used to study residents' perceptions of UA, including questionnaire design, pilot questionnaire, final questionnaire, and data statistical analysis. On this basis, the qualitative analysis method is also used to summarize the development mode, planning, and design strategy of UA in the micro-transformation of old communities.

\subsection{Research Framework}

This study was conducted in three steps. Firstly, the relationship between a healthy community and UA activities was explored to find out whether UA can make a community healthy and sustainable and how to make a community healthy and sustainable through UA. This part is also the background and premise of the whole research. Then, the present situation analysis of old communities, renovation of old communities in Guangzhou, and a creative urban renewal mode "micro-transformation" were analysed. In this part, we focused on the feasibility of integrating UA into the micro-transformation of old communities. The third step was to explore residents' perceptions of old communities and proposed development and design strategies of UA.

Figure 4 illustrates the research framework. 


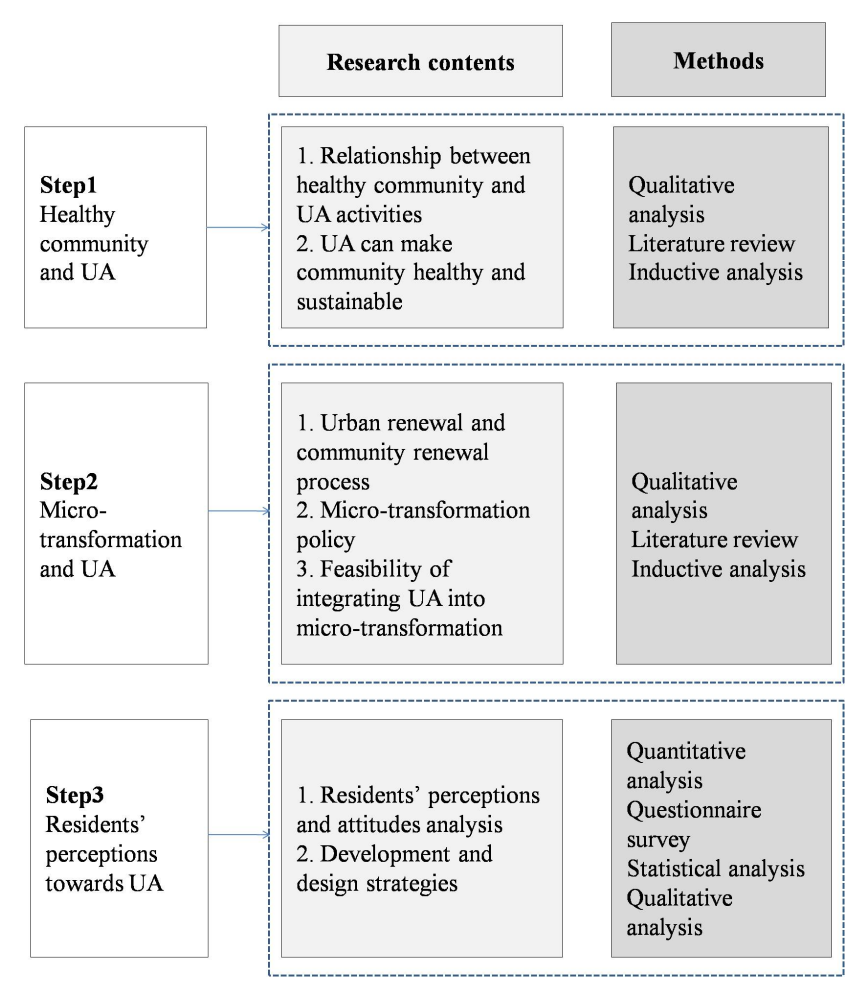

Figure 4. Research framework.

\section{Feasibility of Integrating UA into Micro-Transformation of Old Communities in Guangzhou}

\subsection{Present Situation of Old Communities in China}

According to preliminary statistics, China has nearly 160,000 old communities, involving more than 42 million households and a construction area of approximately 4 billion square meters [68]. An old community records the economic and social development of the city for a period, which is the memory of one generation or even several generations. During the rapid development of urbanization, the infrastructure, supporting facilities, and public space of old communities have long been consumed, and thus cannot meet the living needs of residents [24]. For old community reconstruction, the 'big demolition and big construction' approach is often adopted. Although the modern high-rise residential area built in this way may meet the needs of life, it lacks the original historical features and human feelings. The purpose of the micro-transformation of the old community is to solve the problem of life of the old city residents from the source, improve the living conditions of the people, and improve the appearance of the city [69,70]. It is an important livelihood project with popular feeling. Attention should be paid to the organic renewal, protection, and inheritance during urban construction while meeting the needs of residents.

On 1 December 2017, the MOHURD held a symposium to promote the pilot work of the transformation of old residential areas in Xiamen. The reconstruction of old residential areas is an important measure to solve the problem of unbalanced and inadequate urban development and realise people's yearning for a better life. To promote the transformation of old residential areas is conducive to improving the living conditions and quality of life of residents; improving the sense of access, happiness, and security of the masses; improving the environment of residential areas, continuing the historical context, and realizing the sustainable development of cities; strengthening and innovating social governance at the grassroots level; and creating the social governance structure of co-construction, co-governance, and co-sharing. The pilot project was carried out in 15 cities to better promote the transformation of old residential areas. The purpose was to explore the new mode of the transformation of old residential areas in cities and provide replicable and generalizable experiences for 
promoting the transformation of old residential areas in China. The meeting stressed three principles in the pilot work. The first was to adhere to the people-centred principle, make full use of the concept of 'co-creation', stimulate the enthusiasm of the residents, mobilise the enthusiasm of the relevant units in the community, participate in the transformation of the old community together, and realise decision making, development, co-construction, co-management, effect evaluation, and achievement sharing. The second was to adhere to problem orientation and clarify key contents. The expectations of the masses must be complied, improving the people's livelihood first and then clarifying the key points and contents of the transformation of old residential areas in the near and long term. The third was to adhere to the principle of adjusting measures to local conditions and implementing precise policies [71-73]. Based on fully considering the actual problems of local and old residential areas, a scientific transformation method and planning framework needs to be studied and applied.

\subsection{Renovation of Old Communities in Guangzhou}

At the end of 2017, Guangzhou was selected as the pilot city for the renovation of old residential quarters by the MOHURD, and it was the only first-tier city among the 15 selected cities. Guangzhou's old city renewal work has been deepening and expanding. From the previous simple construction of new buildings to 'addition', it is gradually realising the 'equal emphasis on addition and subtraction' and no longer unilaterally pursuing high volume and economic balance. Great changes have taken place in the core and spirit of urban old environment transformation. In the past, the changes in buildings and their surrounding environment have been paid attention to. What is promoted now is to create a healthy lifestyle and improve the quality of life through the change of urban old environment [74].

A preliminary exploration revealed that the construction safety problems of the old community are prominent and affect the development of the city in 2009. From 2010 to 2014, the Ministry of Land and Resources carried out the 'three old' (old town, old factory building, old village) transformation work. The state-owned land has been promoted effectively, and the stock of land has been activated. From 2015, the Urban Renewal Bureau was established, and the measures of Guangzhou Municipality on urban renewal were implemented. The Urban Renewal Bureau has worked out the implementation plan for the micro-transformation of old residential quarters in Guangzhou in 2017. Guangzhou Urban Renewal Bureau has formulated the three-year (2018-2020) action plan for the micro-transformation of old communities in Guangzhou, and the municipal government has also deliberated and approved the annual plan for urban renewal in 2018 (the second batch). In 2018, Guidelines for the Design of the Micro-transformation of Guangzhou's Old Communities was officially issued. See Figure 5 for details of Guangzhou's micro-transformation.

\subsection{Micro-Transformation of Old Communities}

'Micro-transformation' is a creative urban renewal mode put forward in the measures for urban renewal of Guangzhou implemented in 2016. It refers to a strategy to update the appearance and function of buildings through partial demolition, replacement of building functions, maintenance and repair, renovation, protection, activation, improvement of infrastructure, and other methods under the premise of maintaining the current construction pattern and texture [68]. The micro-transformation includes the micro-transformation of old factory buildings [75,76], old towns [76], old villages [77], and old communities. However, a clear definition of the micro-transformation of old communities does not exist. By combing the literature on community transformation and community renewal and combining the studies with the measures of Guangzhou city renewal issued by the city, the micro-transformation of old communities is defined as one that is led by the government and participated by the market and residents to solve the problems of backward functions and facilities of old communities in the city to improve the living environment of the old community and promote the construction of the social capital of the old community. Multiple cooperative ways can meet the different demands of the residents. 


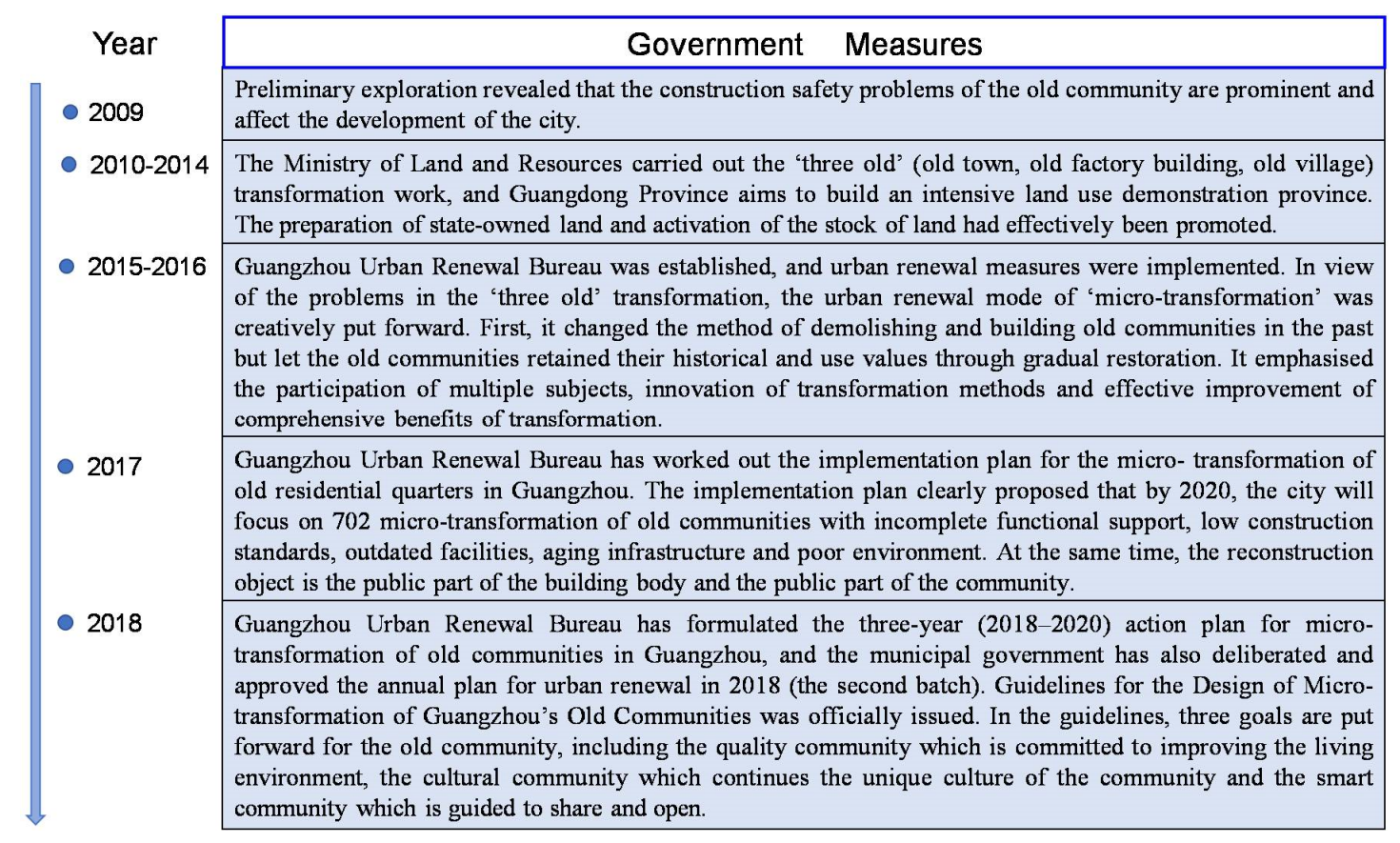

Figure 5. Guangzhou micro-transformation process.

\subsection{Change of the Concept and Management Mode of Community Transformation}

China's community transformation has experienced a process from large-scale demolition and construction to micro-reconstruction. Community construction and management have gradually changed from a top-down management mode to a sharing and co-governance mode, which is also the trend of community development [78]. China's urban residential area management system has been a vertical structure from top to bottom. The residential area management system has developed from the 'unit system' to 'block system' and then to 'community system' and has gradually moved to a multi-body governance system. However, the phenomenon where the government plays a dominant role in the management system remains obvious. Community residents develop an excessive dependence on the government. They are accustomed to passively accepting the role, and lack the enthusiasm to participate in joint governance. Community micro-transformation is a community transformation model that focuses on community co-governance, public participation, and community sharing [79-81]. The micro-transformation of the old community is essentially community governance, and the different interests of the community can be reconciled by forming relationships between the old community micro-reform and cooperation governance and generating interactions and taking joint actions to promote community development.

\subsection{Feasibility of Integrating UA into Micro-Transformation}

During community micro-transformation, many ways can be taken to intervene in micro-transformation, such as art space implantation, industrial upgrading, and other community activation means. Moreover, with the improvement of demand level and the arrival of the experience economy era, people's feelings of human settlements no longer simply stay at the visual level, but pay more attention to the sense and experience of space. Among the many ways, the introduction of a productive landscape into the community micro-transformation can not only improve the community environment and enhance community vitality, but also foster a sense of participation and experience and promote community co-governance and shared development.

According to the analysis above, old communities usually have no production function, poor environment, lack of outdoor space, lack of available types of activities, and low biodiversity of green space. A healthy community includes four aspects of health, namely, healthy production, 
healthy lifestyle, healthy environment and ecosystem, and healthy physical and mental states of residents living in the community. UA has three beneficial features of society, culture, and environment. It is the best strategy that can be possibly supplied the choice to maintain the sustainable development of a city. The intervention of UA in the community can make the community have production function, improve biodiversity, increase the type and time of outdoor activities of residents, and promote the interaction of community residents. Therefore, UA can make an old community healthy and sustainable.

\section{Old Community Residents' Perceptions and Preferences towards UA in Guangzhou}

\subsection{Survey Sites}

Surveys were conducted on 10 old communities which are in Yuexiu district, located in Guangzhou, China (Figure 6, the Chinese characters in the Figure 6 are place names). The area of Yuexiu district is $33.8 \mathrm{~km}^{2}$, and it has 18 streets under its jurisdiction, with a total registered population of 1,158,400 (Sixth Census). Yuexiu district is the oldest central city with the smallest area and the highest population density in Guangzhou. The district has 148 old communities, accounting for $67 \%$ of 222 communities in the district. The plan was to achieve the full coverage of the old residential area transformation through a total of six years, from 2016 to 2021. In 2016 and 2017, 38 community micro-transformation projects were implemented, and they have been completed. There are 70 old communities completed in the city, of which 32 are in Yuexiu district, ranking first. Besides, there are 331 old communities approved in the city, of which 132 are in Yuexiu district, ranking first. However, in the transformed community, the transformation of public space mainly includes the traditional transformation, such as the increase of barrier-free facilities, the renovation of flower beds, the replacement of pavements, and the connection of pedestrian routes, among others. Several communities become involved in art. This study hopes to understand residents' acceptance of UA, and the author hopes to invest in UA in the following micro-transformation projects. As UA has been applied in the community reconstruction of foreign countries and other cities in China, it is well accepted by the residents.

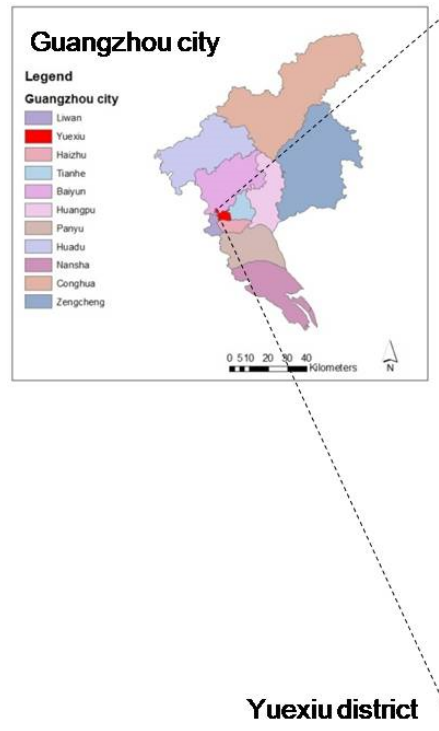

Yuexiu district

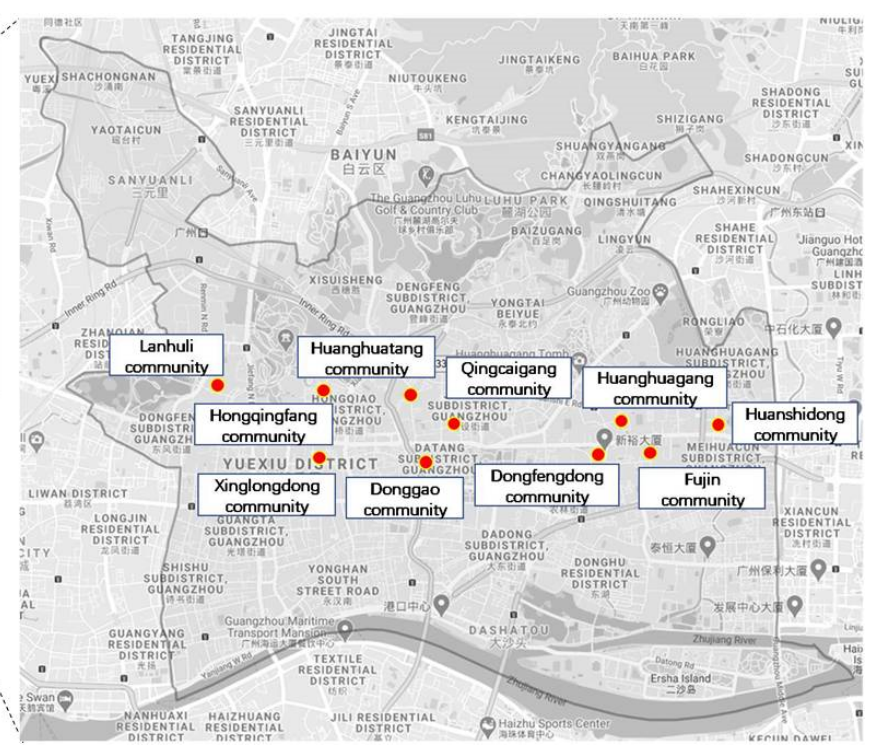

Figure 6. Survey sites.

\subsection{Survey Structure}

The survey consisted of a combination of open and closed questions designed to gather information on the attitudes towards UA participation and its effects on human health and well-being in terms of physical benefits, psychological benefits, and environmental benefits. The questionnaire contained 17 questions, divided into four groups (Table 2). The first group of questions was related to residents' 
demographic information. The second group of questions was related to residents' perceptions of the health benefits of UA. Participants were asked the general health benefit perception of UA in the old community and whether they thought UA provided health and well-being effects based on a five-point Likert scale (where $1=$ strongly disagree, $2=$ disagree, $3=$ undecided, $4=$ agree, $5=$ strongly agree). The third group of questions was related to UA participant intention of residents. The last group consisted of general questions related to what kinds of UA do residents prefer to use in the old community and where. At the end of the survey, respondents had the opportunity to provide personal comments on their thoughts about UA and how it influences their health. Study participants were required greater than or equal to 18 years old and were residents living in old communities of Guangzhou.

Table 2. Survey structure and questionnaire items.

\begin{tabular}{|c|c|c|}
\hline Survey Structure & & Questionnaire Items \\
\hline \multirow{8}{*}{$\begin{array}{l}\text { Group } 1 \text { Demographic } \\
\text { information }\end{array}$} & Gender & 1. Male 2. Female \\
\hline & Age & 1. $18-29$ 2. 30-49 3. 50-69 4. $\geq 70$ \\
\hline & Residency length & 1. $\leq 1$ year 2. $2-4$ years $3.5-9$ years $4 . \geq 10$ years \\
\hline & Employment & $\begin{array}{l}\text { 1. Student 2. Retired 3. Unemployed } \\
\text { 4. White-collar workers 5. Blue-collar workers }\end{array}$ \\
\hline & $\begin{array}{l}\text { Family Income } \\
\text { (per month) }\end{array}$ & $\begin{array}{l}\text { 1. }<3000 \text { RMB 2. } 3000-4999 \text { RMB } \\
\text { 3. 5000-7999 RMB 4. } \geq 8000 \mathrm{RMB}\end{array}$ \\
\hline & Living Status & 1. Single 2 . With family \\
\hline & Children Status & 1. Live without children 2 . Live with children \\
\hline & Rural Living Experience & 1. $\leq 1$ year $2.2-4$ years $3.5-9$ years $4 . \geq 10$ years \\
\hline \multirow[b]{2}{*}{$\begin{array}{l}\text { Group } 2 \text { Perceptions of the health } \\
\text { benefits of UA }\end{array}$} & General health benefits perception & $\begin{array}{l}\text { General health benefits perception of UA in old community } \\
(1=\text { strongly disagree, } 2=\text { disagree, } 3=\text { undecided, } 4=\text { agree, } \\
5=\text { strongly agree })\end{array}$ \\
\hline & $\begin{array}{l}\text { UA human health and well-being } \\
\text { effects }\end{array}$ & $\begin{array}{l}\text { Enrich Green Space Types and Landscape, Provide Experience } \\
\text { of Farming Life, Be Close To Nature, Be Accessed } \\
\text { Conveniently, Increase Community Biodiversity, } \\
\text { Provide Fresh Food, Invigorate Health Effectively, } \\
\text { Increase Physical Activity, Relieve Pressure, } \\
\text { Promote Neighbourhood Communication, Enrich Community } \\
\text { Life, Increase Pleasure (1 = strongly disagree, } 2 \text { = disagree, } \\
3=\text { undecided, } 4=\text { agree, } 5 \text { = strongly agree) }\end{array}$ \\
\hline \multirow{6}{*}{$\begin{array}{l}\text { Group } 3 \\
\text { UA participant intention }\end{array}$} & $\begin{array}{l}\text { Do you support planting } \\
\text { vegetables and fruits in the public } \\
\text { space of the community? }\end{array}$ & 1. Yes 2. No \\
\hline & $\begin{array}{l}\text { Would you like to participate in } \\
\text { planting, harvesting, and } \\
\text { management activities in the } \\
\text { community? }\end{array}$ & 1. Yes 2. No \\
\hline & $\begin{array}{l}\text { What is the main reason to not } \\
\text { support? }\end{array}$ & $\begin{array}{l}\text { 1. May contaminate the community environment } \\
\text { 2. No ornamental plants look good } \\
\text { 3. Management is troublesome } \\
\text { 4. Feel uninteresting or useless }\end{array}$ \\
\hline & $\begin{array}{l}\text { What is the main reason to not } \\
\text { participate? }\end{array}$ & $\begin{array}{l}\text { 1. Cannot plant } \\
\text { 2. Do not have time } \\
\text { 3. Do not like to participate in agricultural activities }\end{array}$ \\
\hline & $\begin{array}{l}\text { How often do you want to } \\
\text { participate? }\end{array}$ & $\begin{array}{l}\text { 1. 1-2 times per week } 2.1-2 \text { times per month } \\
\text { 3. } 3-4 \text { times per year }\end{array}$ \\
\hline & $\begin{array}{l}\text { How much time do you want to } \\
\text { spend on UA every time? }\end{array}$ & 1. $<1$ h $2.1-2$ h $3.2-4$ h \\
\hline \multirow{3}{*}{$\begin{array}{l}\text { Group } 4 \\
\text { Planning and design preferences } \\
\text { towards UA }\end{array}$} & $\begin{array}{l}\text { Which space in the community do } \\
\text { you think is suitable for } \\
\text { agricultural activities? }\end{array}$ & $\begin{array}{l}\text { 1. Central green space } \\
\text { 2. The green space in front of the building } \\
\text { 3. On the top of the roof } \\
\text { 4. Balcony and others }\end{array}$ \\
\hline & $\begin{array}{l}\text { Which planting form do you think } \\
\text { is suitable for the community? }\end{array}$ & $\begin{array}{l}\text { 1. Whole community sharing mode (co-plant, co-harvest, } \\
\text { co-management) } \\
\text { 2. One piece of land or one box for each family }\end{array}$ \\
\hline & $\begin{array}{l}\text { Which planting arrangement form } \\
\text { do you think is suitable for the } \\
\text { community? }\end{array}$ & $\begin{array}{l}\text { 1. All vegetables and fruits } 2 \text {. All flowers } \\
\text { 3. Most vegetables, a small part of flowers } \\
\text { 4. Most flowers, a small part of vegetables }\end{array}$ \\
\hline
\end{tabular}




\subsection{Sampling Method and Data Collection}

A pilot test was conducted on a convenience sample of 50 residents to clarify the wording and amended according to feedback obtained. Finally, 500 printed questionnaires were distributed in 10 old communities from October to November 2019. Fifty questionnaires were distributed to each community, and respondents were approached randomly. The questionnaires were administered using a direct face-to-face survey method because of the relatively high response rate of this method [82]. Finally, a total of 500 questionnaires were collected, for a $100 \%$ return rate. Altogether, 434 were deemed valid and 66 were deemed invalid because of incompleteness, so the valid response rate is $86.8 \%$. With a $95 \%$ confidence level, the sample size needed to yield results that precisely reflect the target population within $\pm 5 \%$ admitted error is 384 . Therefore, the sample size in this study was appropriate.

\subsection{Data Analysis}

Statistical analysis was conducted using IBM Statistical SPSS version 26 . To obtain information on the factor structure of residents' perceptions towards the health benefits of UA, factor analysis using a correlation coefficients matrix of 12 perception items was conducted. The principle axis method, based on the criterion of selecting eigenvalues greater than 1 and varimax rotation of the factors, was used. For analysing differences between demographic characteristics in UA use and perceptions towards health and well-being benefits of UA, descriptive statistics, independent sample $t$-test, and one-way ANOVA were applied. The one-way ANOVA is used to test whether or not the means from three or more groups are significantly different from one another. In this study, descriptive statistics were used to indicate demographic characteristics, and independent sample $t$-test and one-way ANOVA were used to test whether or not the averages of general health benefits perceptions towards UA are significantly different from one another based on variances in personal data.

\section{Results and Discussion}

\subsection{Relationship between Demographic Characteristics and Residents' Perceptions towards General UA Health Benefits}

In this section, when comparing the mean values of general health benefit perceptions towards UA based on variables of gender, living status, and children status, since each variable is divided into two groups, an independent sample $t$-test was used. When comparing three or more mean differences based on age, occupation, and family income, one-way ANOVA was used.

Test of homogeneity of variances was conducted to test whether or not the variance is homogeneous, and the results of Levene statistics showed that $p$ values of the age variable $(p=0.358)$, employment variable $(p=0.473)$, and family income variable $(p=0.929)$ were more than 0.05 , which indicates that the variance is homogeneous, and one-way ANOVA can be used.

Table 3 shows the descriptive statistics of the respondents and the results of independent sample $t$-test and one-way ANOVA. In terms of gender, the ratio of surveyed male and female respondents was almost equal. The participants were composed of $50.9 \%$ women and $49.1 \%$ men (Table 2). The $t$-test for independent samples showed significant differences between gender groups on residents' perceptions towards general UA benefits $(\mathrm{F}=22.750, p=0.000)$. The mean perception of women (mean $=4.34$ ) was higher than that of men (mean $=3.93$ ).

Most of our respondents belonged to the age category of 50-69 years (39.6\%), followed by that of 30-49 years (37.8\%). The age group of 18-29 was represented by $15.2 \%$ of the sample and that of over 70 by $7.4 \%$. One-way ANOVA showed significant differences between age groups on residents' perceptions towards general UA benefits $(\mathrm{F}=3.232, p=0.022<0.05)$. The age category of $50-69$ years appeared to have the highest perception (mean $=4.23$ ) towards UA benefits, followed by that of $30-49$ years $($ mean $=4.15$ ) and the oldest (over 70 years, mean $=4.03$ ). The age group of $18-29$ years showed the lowest perception (mean $=3.92)$. 
Table 3. Demographic characteristics and residents' perceptions of the general health benefits of UA.

\begin{tabular}{|c|c|c|c|c|c|c|}
\hline & \multirow[b]{2}{*}{ Total } & \multirow{2}{*}{$\begin{array}{l}N \\
434\end{array}$} & \multirow{2}{*}{$\begin{array}{c}\% \\
100\end{array}$} & \multicolumn{3}{|c|}{ Perceptions on the General Health Benefits } \\
\hline & & & & Mean & SD & $\begin{array}{c}t \text {-Test } \\
\text { ANOVA Test }\end{array}$ \\
\hline \multirow{2}{*}{ Gender } & Male & 213 & 49.1 & 3.93 & 0.66 & \multirow{2}{*}{$\mathrm{F}=22.750, p=0.000<0.05$} \\
\hline & Female & 221 & 50.9 & 4.34 & 0.71 & \\
\hline \multirow{4}{*}{ Age } & $18-29$ & 66 & 15.2 & 3.92 & 0.71 & \multirow{4}{*}{$\mathrm{F}=3.232, p=0.022<0.05$} \\
\hline & $30-49$ & 164 & 37.8 & 4.15 & 0.70 & \\
\hline & $50-69$ & 172 & 39.6 & 4.23 & 0.73 & \\
\hline & $\geq 70$ & 32 & 7.4 & 4.03 & 0.69 & \\
\hline \multirow{4}{*}{$\begin{array}{l}\text { Residency } \\
\text { length }\end{array}$} & $\leq 1$ year & 42 & 9.7 & 4.07 & 0.64 & \multirow{4}{*}{$\begin{array}{c}\mathrm{F}=1.139 \\
p=0.333>0.05\end{array}$} \\
\hline & $2-4$ years & 59 & 13.6 & 4.00 & 0.69 & \\
\hline & 5-9 years & 123 & 28.3 & 4.16 & 0.68 & \\
\hline & $\geq 10$ years & 210 & 48.4 & 4.18 & 0.76 & \\
\hline \multirow{5}{*}{ Employment } & Student & 23 & 5.3 & 3.73 & 0.69 & \multirow{5}{*}{$\mathrm{F}=2.439, p=0.046<0.05$} \\
\hline & Retired & 180 & 41.5 & 4.19 & 0.72 & \\
\hline & Unemployed & 14 & 3.2 & 3.92 & 0.61 & \\
\hline & White-collar workers & 157 & 36.2 & 4.16 & 0.68 & \\
\hline & Blue-collar workers & 60 & 13.8 & 4.11 & 0.78 & \\
\hline \multirow{4}{*}{$\begin{array}{c}\text { Family } \\
\text { Income } \\
\text { (per month) }\end{array}$} & $<3000$ RMB & 41 & 9.4 & 3.73 & 0.63 & \multirow{4}{*}{$\begin{array}{c}\mathrm{F}=21.496 \\
p=0.00<0.05\end{array}$} \\
\hline & 3000-4999 RMB & 99 & 22.8 & 3.89 & 0.72 & \\
\hline & 5000-7999 RMB & 214 & 49.3 & 4.17 & 0.69 & \\
\hline & $\geq 8000 \mathrm{RMB}$ & 80 & 18.4 & 4.59 & 0.56 & \\
\hline \multirow{2}{*}{ Living Status } & Single & 27 & 6.2 & 3.92 & 0.73 & \multirow{2}{*}{$\mathrm{F}=0.034, p=0.125>0.05$} \\
\hline & With family & 407 & 93.8 & 4.15 & 0.72 & \\
\hline \multirow{2}{*}{$\begin{array}{l}\text { Children } \\
\text { Status }\end{array}$} & Live without children & 233 & 53.7 & 4.12 & 0.67 & \multirow{2}{*}{$\mathrm{F}=8.317, p=0.004<0.05$} \\
\hline & Live with children & 201 & 46.3 & 4.16 & 0.77 & \\
\hline \multirow{4}{*}{$\begin{array}{l}\text { Rural Living } \\
\text { Experience }\end{array}$} & $\leq 1$ year & 291 & 67.1 & 4.09 & 0.74 & \multirow{4}{*}{$\mathrm{F}=1.747, p=0.157>0.05$} \\
\hline & $2-4$ years & 16 & 3.7 & 4.12 & 0.80 & \\
\hline & $5-9$ years & 24 & 5.5 & 4.08 & 0.50 & \\
\hline & $\geq 10$ years & 103 & 23.7 & 4.28 & 0.66 & \\
\hline
\end{tabular}

In terms of work status, almost half of the respondents were retired (41.5\%), whereas $36.2 \%$ of the respondents were white-collar workers, followed by $13.8 \%$ blue-collar workers, $5.3 \%$ of students, and $3.2 \%$ unemployed. The ANOVA test showed significant differences among employments on residents' perceptions towards general UA benefits $(\mathrm{F}=2.439, p=0.046<0.05)$. The mean perceptions of retired (mean $=4.19, p=0.004$ ), white-collar workers (mean $=4.16, p=0.008$ ), and blue-collar workers (mean $=4.11, p=0.032$ ) are higher than those of students (mean $=3.7391$ ).

Almost half of the respondents lived in the communities for over 10 years, 28.3\% lived 5-9 years, $13.6 \%$ lived $2-4$ years, and $9.7 \%$ lived less than 1 year. The ANOVA test showed no significant differences among residency length on residents' perceptions towards general UA benefits $(\mathrm{F}=1.139$, $p=0.333>0.05)$.

In terms of family income level, $49.3 \%$ of the interviewed people's family income was 5000-7999 RMB per month, $22.8 \%$ was 3000-4999 RMB per month, 9.4\% was less than 3000 RMB per month, and $18.4 \%$ was over 8000 RMB per month. One-way ANOVA showed significant differences among family income levels on residents' perceptions towards general UA benefits $(\mathrm{F}=21.496$, $p=0.000$ ). The mean perceptions of those earning over $8000 \mathrm{RMB}$ per month (mean $=4.59, p=0.000$ ) were higher than those earning 5000-7999 RMB per month (mean $=4.17, p=0.000$ ), 3000-4999 RMB per month (mean $=3.89, p=0.000$ ), and less than $3000 \mathrm{RMB}$ per month (mean $=3.73, p=0.000$ ).

In terms of income resident status, $93.8 \%$ of the participants lived with family, and $6.2 \%$ lived without family. The $t$-test for independent samples showed that no significant differences between resident status on residents' perceptions towards general UA benefits $(\mathrm{F}=0.034, p=0.125)$.

More than half of the participants lived in rural areas for less than one year, with a ratio of $67.1 \%$, and $23.7 \%$ lived more than 10 years. One-way ANOVA showed no significant differences among rural living experience on residents' perceptions towards general UA benefits $(F=1.747, p=0.157)$. 
Of the participants, $53.7 \%$ lived without children, and $46.3 \%$ lived with children. The $t$-test for independent samples showed significant differences between the status of children on residents' perceptions towards general UA benefits $(\mathrm{F}=8.317, p=0.004)$. The mean perceptions of the respondents with children $($ mean $=4.16)$ were higher than those without children $($ mean $=4.12)$.

The analysis results showed significant differences between gender groups and the status of children on old community residents' perceptions towards general UA benefits. Women's perceptions were higher than men's. The residents of old communities held a supportive attitude towards the whole UA with high scores. Compared with men, women had a higher evaluation of the health benefits of integrating UA into old communities. The mean perceptions of the respondents with children were higher than those without. Residents with children expressed that UA can enrich their children's extra-curricular life, educate their children in agriculture through urban agricultural activities, and promote parent-child relationship. There were also significant differences among age groups, employment, and family income levels. The age group of 50-69 years appeared to have the highest perceptions towards UA benefits, followed by that of 30-49 years, oldest (over 70 years), and 18-29 years. Retired residents appeared to have the highest perceptions, followed by white-collar workers, blue-collar workers, and students. Most of the residents aged 50-69 were retired. In the interview, most of them expressed their approval for the development of UA in the old communities. Some people thought that the development of cities can make their families eat their own vegetables and feel safe and assured. Some people mentioned that it can save physical strength and time without going to the market every day. Some people thought that the UA can provide for them, enable family outdoor activities, feel very fun, and allow them to know other people in the community. The mean perceptions of those earning over $8000 \mathrm{RMB}$ per month were higher than those earning 5000-7999 RMB, 3000-4999 RMB, and less than 3000 RMB. High-income groups paid more attention to food safety, physical and mental health, and other issues.

\subsection{Factors of the Perceptions towards UA Benefits}

The reliability of residents' perception items of the health benefits of UA was 0.911 using Cronbach's alpha measure, which showed the good reliability of the whole data.

The mean ratings of the 12 items indicated that many residents felt that UA in old communities can increase physical activity (4.09), provide fresh food (4.08), be close to nature (4.06), invigorate health effectively (4.05), relieve pressure (4.04), be accessed conveniently (4.02), increase community biodiversity (4.00), enrich green space types and landscape (3.98), provide the experience of farming life (3.95), promote neighbourhood communication (3.75), enrich community life (3.65), and increase pleasure (3.46).

To extract the factors of residents' perceptions towards the UA benefits among 12 variables, factor analysis was conducted. Based on the factor analysis of a matrix of the 12 perception items, three factors were found that accounted for $81.854 \%$ of the total variance among all judgments. Factor loadings and communalities for the items are shown in Table 4. Based on an inspection of the factor loadings, the factors were labelled as follows: Factor 1, accounting for $34.018 \%$ of the total variance, was called 'environmental health benefits'; factor 2, accounting for $28.598 \%$, was called 'physical and psychological health benefits'; factor 3, accounting for $19.238 \%$, was called 'community health benefits'. Physical and mental health factors could explain the most results, which showed that residents paid more attention to the health benefits of UA. The health benefits of UA are mainly reflected in three aspects: Environment and ecosystem, physical and mental development of residents, and community development. According to the perceptions of UA health benefits by residents, it can be seen that the health benefits of UA were highly evaluated by residents, and residents do hold a positive attitude towards UA. Therefore, the UA development in the micro-transformation of old communities can improve the health of communities, such as enhancing the biodiversity of the community, improving the ecosystem service function, providing physical exercise opportunities for 
residents, promoting the mental health of residents, promoting the sense of community, and promoting the sustainable development of the community.

Table 4. Factor analysis of the perception of UA benefits.

\begin{tabular}{|c|c|c|c|c|c|}
\hline \multicolumn{6}{|c|}{ Component } \\
\hline & 1 & 2 & 3 & Mean & SD \\
\hline $\begin{array}{c}\text { Enrich Green Space Types } \\
\text { and Landscape }\end{array}$ & 0.941 & 0.113 & 0.110 & 3.98 & 0.74 \\
\hline $\begin{array}{c}\text { Provide the Experience of } \\
\text { Farming Life }\end{array}$ & 0.903 & 0.131 & 0.068 & 3.95 & 0.74 \\
\hline Be Close to Nature & 0.880 & 0.254 & 0.170 & 4.06 & 0.81 \\
\hline Be Accessed Conveniently & 0.860 & 0.107 & 0.124 & 4.02 & 0.77 \\
\hline $\begin{array}{c}\text { Increase Community } \\
\text { Biodiversity }\end{array}$ & 0.856 & 0.090 & 0.021 & 4.00 & 0.77 \\
\hline Provide Fresh Food & 0.120 & 0.908 & 0.217 & 4.08 & 0.71 \\
\hline $\begin{array}{c}\text { Invigorate Health } \\
\text { Effectively }\end{array}$ & 0.144 & 0.859 & 0.185 & 4.05 & 0.71 \\
\hline Increase Physical Activity & 0.169 & 0.856 & 0.298 & 4.09 & 0.72 \\
\hline Relieve Pressure & 0.160 & 0.833 & 0.215 & 4.04 & 0.76 \\
\hline $\begin{array}{l}\text { Promote Neighbourhood } \\
\text { Communication }\end{array}$ & 0.101 & 0.316 & 0.892 & 3.75 & 0.95 \\
\hline Enrich Community Life & 0.105 & 0.171 & 0.886 & 3.65 & 0.81 \\
\hline Increase Pleasure & 0.155 & 0.446 & 0.672 & 3.46 & 1.09 \\
\hline
\end{tabular}

Linear regression was conducted to look into the relationship between the general health benefit and extracted factors (Table 5). The results were as follows: General health benefit $=0.107 \times$ factor 1 (environmental health benefits) $+0.626 \times$ factor 2 (physical and psychological health benefits) + $0.207 \times$ factor 3 (community health benefits). Physical and mental health factors could explain the most results, which showed that residents paid more attention to the health benefits of UA.

Table 5. Linear regression of the general health benefit and factors.

\begin{tabular}{|c|c|c|c|c|c|}
\hline \multirow[t]{2}{*}{ Model } & \multicolumn{2}{|c|}{$\begin{array}{l}\text { Unstandardized } \\
\text { Coefficients }\end{array}$} & \multirow{2}{*}{$\begin{array}{l}\begin{array}{l}\text { Standardized } \\
\text { Coefficients }\end{array} \\
\text { Beta }\end{array}$} & \multirow[t]{2}{*}{$t$} & \multirow[t]{2}{*}{ Sig. } \\
\hline & B & Std. Error & & & \\
\hline (Constant) & 4.141 & 0.013 & & 320.808 & 0.000 \\
\hline Environmental Health Benefits & 0.107 & 0.013 & 0.149 & 8.286 & 0.000 \\
\hline Physical and Psychological Health Benefits & 0.626 & 0.013 & 0.870 & 48.458 & 0.000 \\
\hline Community Health Benefits & 0.207 & 0.013 & 0.288 & 16.044 & 0.000 \\
\hline
\end{tabular}

\subsection{Support and Participant Intention of UA in Old Communities}

Of the respondents, $91.5 \%$ expressed support intention of UA in their communities, and $89.2 \%$ expressed the desire to participate in UA activities in their communities. The reason for not supporting the development of UA in the old community was that the later maintenance is troublesome. The next reason was that UA is not as beautiful as ornamental plants. Some people thought that UA may contaminate the community environment and feel uninteresting or useless. The main reason they do not want to participate in UA was that they do not have time to do that. Some residents thought they cannot, so they do not want to participate. Some people did not like to participate in agricultural activities.

As shown in Table 6, the majority of respondents stated that they were willing to spend 1-2 times per week $(41.9 \%)$ and $1-2 \mathrm{~h}(45.6 \%)$ per time on UA activities, followed by those who intended to spend 1-2 times per month (29.0\%) and 3-4 times per year (18.4\%), less than 1 hour per time (24.7\%) 
and $2-4 \mathrm{~h}(19.1 \%)$. The ANOVA showed that the participation frequency and the time spent using UA did not differ significantly between demographic characteristics.

Table 6. Support and participant intention of UA in old communities.

\begin{tabular}{cccc}
\hline & Items & $\mathbf{N}$ & $\mathbf{\%}$ \\
\hline \multirow{3}{*}{ Main Reason to not Support } & Total & 37 & 8.5 \\
& May contaminate the community environment & 8 & 1.8 \\
& No ornamental plants look good & 9 & 2.1 \\
& Management is troublesome & 17 & 3.9 \\
Main Reason to not Participate & Feel uninteresting or useless & 3 & 0.7 \\
& Total & 47 & 10.8 \\
& Cannot plant & 16 & 3.7 \\
& Do not like to participate in agricultural activities & 27 & 6.2 \\
Participate Frequency & Total & 4 & 0.9 \\
\hline \multirow{2}{*}{ Time Spent } & $1-2$ times per week & 388 & 89.3 \\
& $1-2$ times per month & 182 & 41.9 \\
& 3-4 times per year & 80 & 29.0 \\
& $<1 \mathrm{~h}$ & 107 & 18.4 \\
\hline
\end{tabular}

The results showed that almost all residents supported the development of UA in the old communities and expressed their willingness to participate in various activities of UA. Residents who did not support the development of UA were mainly worried about maintenance, planting effect, environmental pollution, and so on, and residents who did not want to participate expressed the idea of no time and no planting experience, among others. Therefore, in the actual development process, the first thing to solve is the maintenance problem. The two ways to address this are community-centralised management and residents' own management. Besides, lectures on UA knowledge can be held regularly, and experts can be hired to train residents in the cultivation and maintenance of vegetables and fruits. The mode of mutual help and mutual assistance with the village can be formed, and the old community residents can be trained by the farmers in the village, which not only solves the residents' concerns, but also promotes the employment of the rural population.

\subsection{UA Forms and Types in Old Communities}

Table 7 displays UA forms and types preferred by residents of old communities. In terms of UA location and forms, $56.9 \%$ of the respondents supported participation in planting, harvesting, and management activities in the community in the green space in front of the buildings (56.9\%), followed by on the top of the roof $(14.5 \%)$, central green space $(11.8 \%)$, and balcony $(6.2 \%)$.

More than half of the respondents (58.1\%) were inclined towards the whole community sharing mode (co-plant, co-harvest, co-management) to develop UA activities in old communities. Of the respondents, $31.3 \%$ tended one piece of land or one box for each family to develop UA activities. In terms of planting arrangement, $39.2 \%$ of respondents chose all vegetables and fruits, $31.1 \%$ chose most vegetables and a small part of flowers, and $14.3 \%$ chose most flowers and a small part of vegetables.

Since the implementation of micro-transformation of old communities, governments at all levels have actively promoted community co-construction through various ways and channels to stimulate the enthusiasm of community residents to participate in community transformation and development [78]. The survey results showed that the community governance mode of co-construction and sharing has been accepted by community residents. UA involved in the micro-transformation of old communities is a good way to develop community co-construction and sharing. 
Table 7. UA forms and types in old communities.

\begin{tabular}{cccc}
\hline & Items & $\mathbf{N}$ & $\mathbf{\%}$ \\
\hline \multirow{4}{*}{ UA Location } & Total & 388 & 89.3 \\
& Central green space & 51 & 11.8 \\
& The green space in front of the buildings & 247 & 56.9 \\
& On the top of the roof & 63 & 14.5 \\
& Balcony and others & 27 & 6.2 \\
\hline \multirow{3}{*}{ Land Use Form } & Whole community sharing mode (co-plant, & 252 & 58.1 \\
& co-harvest, co-management) & 136 & 31.3 \\
\hline \multirow{3}{*}{ Planting Form } & One piece of land or one box for each family & 170 & 39.2 \\
& All vegetables and fruits & 21 & 4.8 \\
& All flowers & 135 & 31.1 \\
& Most vegetables, a small part of flowers & 62 & 14.3 \\
\hline
\end{tabular}

\subsection{Implications for UA Development in the Micro-Transformation of Old Communities}

China's urban planning has changed from top-down to bottom-up in recent years and public participation has been emphasized. Community planning and building are also experiencing such changes, and co-construction and co-sharing have become the focus of community development. Through the analysis of the present situation of old communities in China, the renewal process of old communities in Guangzhou, the concept of micro-transformation of old communities, and the analysis of policies and models of micro-transformation of old communities in Guangzhou, as well as the analysis of UA features, we have proposed that it is feasible to integrate UA into the planning and design stage of community micro-transformation. Moreover, according to the previous analysis, UA, as a form of the community garden, has social, environmental, economic, and other functions, and has been accepted by residents in Western countries, Japan, and South Korea with good development experiences, which can make the community healthy and lead to sustainable development. However, it is only in its infancy in China. At present, there are several good cases [83] in a few cities such as Beijing Little Donkey Farm, Shanghai Initiative Garden [64], Baicao Garden, and the Children's Garden in Hunan Agricultural University [84]. Guangzhou is one of the pilot cities in China to carry out community micro-transformation. The transformation of community public open space is one of the key contents of micro-transformation. Many communities in Guangzhou have adopted the form of integrating art into public open space, and UA will also be a very good form of intervention.

Through the statistical analysis of UA support attitude, participation frequency, time spent, construction location, development style and form, and through interviews, when developing UA in old communities, the three development strategies are as follows: (1) Construction and management mode, (2) planning mode, and (3) promotion mode. The first mode entails promoting and forming the community construction and governance mode of co-construction and co-sharing. The integration of UA in the micro-transformation of old communities is conducive to co-construction and co-sharing mode. Therefore, the use of UA planning strategies in the renewal and micro-transformation of old communities is conducive to the implementation of the concept of 'co-creation'. 'Co-creation' means co-planning, co-construction, and co-sharing. The maintenance of old communities' UA in the later stage can adopt the combination of community-centralized maintenance and personal maintenance. The maintenance cost is not involved in this study. However, through interviews, most residents said that the maintenance cost should be borne by the government or the community. If the community adopts the centralized maintenance mode and the participating residents have to pay, then they are willing to bear less maintenance costs. Therefore, the amount of maintenance costs and payment methods should be further analysed and studied in combination with residents' income. The planning mode has changed from the top-down government-led mode to the bottom-up public participation mode. During the development of UA in old communities, public participation mode should be encouraged; community planners and designers should actively listen to the opinions of the residents 
on UA and try to meet the needs of community residents so that they can act as planners and designers. Some communities, although not the communities mainly developing UA, have begun to explore this aspect, looking for capable people in the community and allowing them to participate in community planning. It can also enrich the spare time life of community residents, make the residents communicate with one another, and realize the concept of community 'co-creation'. Public participation in UA planning is essential. In the promotion mode, according to China's current situations, the community garden development foundation is relatively insufficient. The development of UA will also encounter many difficulties and problems, through the above analysis, we can see that residents who did not support the development of UA were mainly worried about plant selection, planting technology, and maintenance, and residents who did not want to participate expressed the idea of no planting experience. To better promote and develop UA in old communities, increase residents' interest, and enable them to gain something from their work, UA lectures on the introduction of excellent cases at home and abroad, and the functions of UA can be carried out regularly. The residents can then understand UA in the community and be introduced to the agricultural technologies related to UA from the aspects of seed selection, cultivation, maintenance, and harvest. Residents can get training and practice. Parent-child gardening, holiday farm, weekend picking, and other activities can be held on holidays and weekends.

In turn, the following three planning and design strategies are important: (1) Construction location, (2) design style, and (3) seasonal design. The spatial carrier of community UA is mainly the public green space in the community. According to the survey, most of the old community residents prefer to build UA on the public green space in front of the community residential buildings. A small number of residents tend to use the roof space and the central green space to develop community UA, and fewer residents think that they can use balcony space for development. Therefore, priority can be given to the construction of UA in front of residential buildings, which is more convenient for residents, especially for the elderly. In terms of design style, most of the residents support the planting of all vegetables and fruits in the UA of the community, whereas some support the planting of most vegetables and a small number of flowers. Other residents are worried about the ornamental effect of the community garden and think that the form of planting flowers and vegetables as a supplement is better. Therefore, the community UA should develop an edible and productive landscape mainly composed of vegetables and fruits, supplemented by ornamental flower planting at the entrance, central garden, and focal position to achieve the effect of combining production and ornaments. Most of the residents support the cultivation of all vegetables and fruits, or most of them, and a small number of ornamental plants. Concerning seasonal design, the main problem faced by the landscape type of production materials is the seasonal problem. To make full use of space and time, seasonal edible plants are designed in the green space of old communities.

\section{Conclusions and Limitations}

Nowadays, the place of community UA is no longer a simple food production land, but also a community exchange and interaction centre. It has a catalytic effect on community construction, and one of the advantages is that it directly contributes to the promotion of a healthy community.

This study explored the elements that healthy communities need to have and the feasibility of using UA as a community garden form in a large number of old community micro-transformation projects in China. We also focused on old community residents' perceptions of the health benefits of UA. A survey questionnaire was used to grasp residents' acceptance of UA and their preferences for planning and design forms of UA. A large number of micro-transformation projects are being carried out and will be carried out in Guangzhou and other cities in China. We proposed that more agricultural activities could be integrated into community open spaces, enrich the outdoor activities, and improve the physical and mental health of the residents. Through the intervention of UA, the community can form the co-construction and co-sharing mode, form the community cohesion, and make the community healthy and lead to sustainable development. This study did not quantitatively examine the 
health benefits of UA. Future studies should employ a mix of medical experiments and questionnaires into the research.

Author Contributions: Conceptualization, Y.M.; methodology, Y.M.; theoretical analysis, H.L. (Heng Liang); investigation, H.L. (Han Li) and Y.L.; data analysis, Y.M., H.L. (Heng Liang) and Y.L.; writing一original draft preparation, Y.M. and H.L. (Heng Liang); writing-review and editing, Y.M. All authors have read and agreed to the published version of the manuscript.

Funding: This work was supported by the National Natural Science Foundation of China (No. 51708127), the Opening Funds of State Key Laboratory of Building Safety and Built Environment and National Engineering Research Center of Building Technology (No. BSBE2018-01), and Program of Study Abroad for Excellent teacher at Guangdong University of Technology.

Acknowledgments: We would like to thank National Natural Science Foundation of China. We would also like to thank all of the participants who actively participated in the investigation.

Conflicts of Interest: The authors declare no conflict of interest.

\section{References}

1. Harpham, T. Urbanisation and health in transition. Lancet 1997, 349, S11-S13. [CrossRef]

2. Du, X.; Huang, Z. Ecological and environmental effects of land use change in rapid urbanization: The case of Hangzhou, China. Ecol. Indic. 2017, 81, 243-251. [CrossRef]

3. Carmon, N. Three generations of urban renewal policies: Analysis and policy implications. Geoforum 1999, 30, 145-158. [CrossRef]

4. Mehdipanah, R.; Malmusi, D.; Muntaner, C.; Borrell, C. An evaluation of an urban renewal program and its effects on neighborhood resident's overall wellbeing using concept mapping. Health Place 2013, 23, 9-17. [CrossRef]

5. Mehdipanah, R.; Manzano, A.; Borrell, C.; Malmusi, D.; Rodriguez-Sanz, M.; Greenhalgh, J.; Muntaner, C.; Pawson, R. Exploring complex causal pathways between urban renewal, health and health inequality using a theory-driven realist approach. Soc. Sci. Med. 2015, 124, 266-274. [CrossRef]

6. Harpham, T. Urban health in developing countries: What do we know and where do we go? Health Place 2009, 15, 107-116. [CrossRef]

7. Moore, M.; Gould, P.; Keary, B.S. Global urbanization and impact on health. Int. J. Hyg. Environ. Health 2003, 206, 269-278. [CrossRef]

8. Tao, Y.; Zhang, Z.; Ou, W.; Guo, J.; Pueppke, S.G. How does urban form influence PM2.5 concentrations: Insights from 350 different-sized cities in the rapidly urbanizing Yangtze River Delta region of China, 1998-2015. Cities 2020, 98, 102581. [CrossRef]

9. Zhang, X.; Gu, X.; Cheng, C.; Yang, D. Spatiotemporal heterogeneity of PM2.5 and its relationship with urbanization in North China from 2000 to 2017. Sci. Total Environ. 2020, 744, 140925. [CrossRef]

10. Li, G.; Zhang, X.; Mirzaei, P.A.; Zhang, J.; Zhao, Z. Urban heat island effect of a typical valley city in China: Responds to the global warming and rapid urbanization. Sustain. Cities Soc. 2018, 38, 736-745. [CrossRef]

11. Popkin, B.M. Urbanization, lifestyle changes and the nutrition transition. World Dev. 1999, 27, $1905-1916$. [CrossRef]

12. Walker, A.; Adam, F.; Walker, B. World pandemic of obesity: The situation in Southern African populations. Public Health 2001, 115, 368-372. [CrossRef]

13. Durand, M.; Wilson, J.G. Spatial analysis of respiratory disease on an urbanized geothermal field. Environ. Res. 2006, 101, 238-245. [CrossRef] [PubMed]

14. Tajudin, M.A.B.A.; Khan, M.F.; Mahiyuddin, W.R.W.; Hod, R.; Latif, M.T.; Hamid, A.H.; Abd Rahman, S.; Sahani, M. Risk of concentrations of major air pollutants on the prevalence of cardiovascular and respiratory diseases in urbanized area of Kuala Lumpur, Malaysia. Ecotoxicol. Environ. Saf. 2019, 171, 290-300. [CrossRef] [PubMed]

15. Gong, P.; Liang, S.; Carlton, E.J.; Jiang, Q.; Wu, J.; Wang, L.; Remais, J.V. Urbanisation and health in China. Lancet 2012, 379, 843-852. [CrossRef]

16. Berra, K.; Franklin, B.; Jennings, C. Community-based healthy living interventions. Prog. Cardiovasc. Dis. 2017, 59, 430-439. [CrossRef] [PubMed] 
17. Harpham, T. Urbanization and mental health in developing countries: A research role for social scientists, public health professionals and social psychiatrists. Soc. Sci. Med. 1994, 39, 233-245. [CrossRef]

18. Ludermir, A.B.; Harpham, T. Urbanization and mental health in Brazil: Social and economic dimensions. Health Place 1998, 4, 223-232. [CrossRef]

19. Shaikh, M.; Levina, N. Selecting an open innovation community as an alliance partner: Looking for healthy communities and ecosystems. Res. Policy 2019, 48, 103766. [CrossRef]

20. Kohon, J. Social inclusion in the sustainable neighborhood? Idealism of urban social sustainability theory complicated by realities of community planning practice. City Cult. Soc. 2018, 15, 14-22. [CrossRef]

21. Zheng, H.W.; Shen, G.Q.; Wang, H. A review of recent studies on sustainable urban renewal. Habitat Int. 2014, 41, 272-279. [CrossRef]

22. Wang, H.; Shen, Q.; Tang, B.-S.; Lu, C.; Peng, Y.; Tang, L. A framework of decision-making factors and supporting information for facilitating sustainable site planning in urban renewal projects. Cities 2014, 40, 44-55. [CrossRef]

23. Liu, L.; Jensen, M.B. Green infrastructure for sustainable urban water management: Practices of five forerunner cities. Cities 2018, 74, 126-133. [CrossRef]

24. Shaw, V.N. Urban housing reform in China. Habitat Int. 1997, 21, 199-212. [CrossRef]

25. Wang, W.; Wu, Y.; Sloan, M. A framework \& dynamic model for reform of residential land supply policy in urban China. Habitat Int. 2018, 82, 28-37.

26. Zhang, Y.; Fang, K. Politics of housing redevelopment in China: The rise and fall of the Ju'er Hutong project in inner-city Beijing. J. Hous. Built Environ. 2003, 18, 75-87. [CrossRef]

27. Yi, Z.; Liu, G.; Lang, W.; Shrestha, A.; Martek, I. Strategic approaches to sustainable urban renewal in developing countries: A case study of Shenzhen, China. Sustainability 2017, 9, 1460. [CrossRef]

28. Qing, L. Study on Residents' Participation in Community Governance in Old Area of Quanzhou-Taking H Community in Quanzhou as an example. J. Chengdu Aeronaut. Polytech. 2017, 2, 27.

29. Xuan, S. The Transformation of Community Governance and the Construction of a New Order. J. Jianghan Univ. Soc. Sci. Ed. 2015, 6, 12.

30. Yang, Z.; Zhong, L. Learning from the "Residential Community" Consciousness Training of Community Governance in Taiwan: Reflection on the Community Governance of Old Residential Cistrict of Chengdu. Mod. Urban Res. 2017, 9, 11.

31. Koehler, K.; Latshaw, M.; Matte, T.; Kass, D.; Frumkin, H.; Fox, M.; Hobbs, B.F.; Wills-Karp, M.; Burke, T.A. Building healthy community environments: A public health approach. Public Health Rep. 2018, 133, 35S-43S. [CrossRef] [PubMed]

32. Morris, A.; Zuo, J.; Wang, Y.; Wang, J. Readiness for sustainable community: A case study of Green Star Communities. J. Clean. Prod. 2018, 173, 308-317. [CrossRef]

33. Chirico, F. Spiritual well-being in the 21st century: It's time to review the current WHO's health definition. J. Health Soc. Sci. 2016, 1, 11-16.

34. Leonardi, F. The definition of health: Towards new perspectives. Int. J. Health Serv. 2018, 48, 735-748. [CrossRef] [PubMed]

35. Wu, Z.; Shan, J. A Study on the Evolution and Optimization of Production-Ecological-Living Space Structure in Chinese Cities. Chin. J. Urban Environ. Stud. 2019, 7, 1950018. [CrossRef]

36. Wang, D.; Jiang, D.; Fu, J.; Lin, G.; Zhang, J. Comprehensive Assessment of Production-Living-Ecological Space Based on the Coupling Coordination Degree Model. Sustainability 2020, 12, 2009. [CrossRef]

37. Azunre, G.A.; Amponsah, O.; Peprah, C.; Takyi, S.A.; Braimah, I. A review of the role of urban agriculture in the sustainable city discourse. Cities 2019, 93, 104-119. [CrossRef]

38. Ferreira, A.J.D.; Guilherme, R.I.M.M.; Ferreira, C.S.S. Urban agriculture, a tool towards more resilient urban communities? Curr. Opin. Environ. Sci. Health 2018, 5, 93-97. [CrossRef]

39. Contesse, M.; van Vliet, B.J.; Lenhart, J. Is urban agriculture urban green space? A comparison of policy arrangements for urban green space and urban agriculture in Santiago de Chile. Land Use Policy 2018, 71, 566-577. [CrossRef]

40. Hallett, S.; Hoagland, L.; Toner, E.; Gradziel, T.; Mitchell, C.; Whipkey, A. Urban agriculture: Environmental, economic, and social perspectives. Hortic. Rev. 2016, 44, 65-120.

41. Orsini, F.; Dubbeling, M.; De Zeeuw, H.; Gianquinto, G. Rooftop Urban Agriculture; Springer: Berlin/Heidelberg, Germany, 2017. 
42. Walters, S.A.; Stoelzle Midden, K. Sustainability of urban agriculture: Vegetable production on green roofs. Agriculture 2018, 8, 168. [CrossRef]

43. Mougeot, L.J.A. Urban agriculture: Definition, presence, potentials and risks, and policy challenges. In Growing Cities, Growing Food: Urban Agriculture on the Policy Agenda; DSE: Feldafing, Germany, 2000; Volume 1, pp. 1-42.

44. Yadav, A.N.; Kumar, R.; Kumar, S.; Kumar, V.; Sugitha, T.; Singh, B.; Chauhan, V.; Dhaliwal, H.S.; Saxena, A.K. Beneficial microbiomes: Biodiversity and potential biotechnological applications for sustainable agriculture and human health. J. Appl. Biol. Biotechnol. 2017, 5, 45-57.

45. Horst, M.; McClintock, N.; Hoey, L. The intersection of planning, urban agriculture, and food justice: A review of the literature. J. Am. Plann. Assoc. 2017, 83, 277-295. [CrossRef]

46. Mills, J.G.; Weinstein, P.; Gellie, N.J.; Weyrich, L.S.; Lowe, A.J.; Breed, M.F. Urban habitat restoration provides a human health benefit through microbiome rewilding: The Microbiome Rewilding Hypothesis. Restor. Ecol. 2017, 25, 866-872. [CrossRef]

47. Flies, E.J.; Skelly, C.; Lovell, R.; Breed, M.F.; Phillips, D.; Weinstein, P. Cities, biodiversity and health: We need healthy urban microbiome initiatives. Cities Health 2018, 2, 143-150. [CrossRef]

48. Flies, E.J.; Skelly, C.; Negi, S.S.; Prabhakaran, P.; Liu, Q.; Liu, K.; Goldizen, F.C.; Lease, C.; Weinstein, P. Biodiverse green spaces: A prescription for global urban health. Front. Ecol. Environ. 2017, 15, 510-516. [CrossRef]

49. Panagopoulos, T.; Jankovska, I.; Dan, M.B. Urban green infrastructure: The role of urban agriculture in city resilience. Urban. Arhit. Constr. 2018, 9, 55.

50. Grunewald, K.; Li, J.; Xie, G.; Kümper-Schlake, L. Towards Green Cities: Urban Biodiversity and Ecosystem Services in China and Germany; Springer: Berlin/Heidelberg, Germany, 2018.

51. Newton, L. Urban Agriculture and Community Values: The Green Transformation of Cities; Springer Nature: Berlin/Heidelberg, Germany, 2020.

52. Akpinar, A. How is quality of urban green spaces associated with physical activity and health? Urban For. Urban Green. 2016, 16, 76-83. [CrossRef]

53. Dadvand, P.; Bartoll, X.; Basagaña, X.; Dalmau-Bueno, A.; Martinez, D.; Ambros, A.; Cirach, M.; Triguero-Mas, M.; Gascon, M.; Borrell, C. Green spaces and general health: Roles of mental health status, social support, and physical activity. Environ. Int. 2016, 91, 161-167. [CrossRef]

54. Han, K.-T. The effect of nature and physical activity on emotions and attention while engaging in green exercise. Urban For. Urban Green. 2017, 24, 5-13. [CrossRef]

55. Kim, E.S.; Kubzansky, L.D.; Soo, J.; Boehm, J.K. Maintaining healthy behavior: A prospective study of psychological well-being and physical activity. Ann. Behav. Med. 2017, 51, 337-347. [CrossRef] [PubMed]

56. Mamun, S.; Hasan, M.; Afrin, R.; Hasan, M. Use of Kitchen Waste in Rooftop Vegetable Production-A Review. J. Environ. Sci. Nat. Resour. 2018, 11, 253-259.

57. Wang, Z.; Li, C.; Yang, T.; Yang, L.; Liu, F. Research on Quality Improvement Planning of Old Community. Planners 2017, 11, 3.

58. Zhang, Q.-Q.; Li, H. Research on Open Space Strategy of Old Community. Build. Technol. Dev. 2017, 16, 14.

59. Skar, S.; Pineda-Martos, R.; Timpe, A.; Pölling, B.; Bohn, K.; Külvik, M.; Delgado, C.; Pedras, C.; Paço, T.; Ćujić, M. Urban agriculture as a keystone contribution towards securing sustainable and healthy development for cities in the future. Blue Green Syst. 2020, 2, 1-27. [CrossRef]

60. McClintock, N. Cultivating (a) sustainability capital: Urban agriculture, ecogentrification, and the uneven valorization of social reproduction. Ann. Am. Assoc. Geogr. 2018, 108, 579-590. [CrossRef]

61. Lovell, S.T. Multifunctional urban agriculture for sustainable land use planning in the United States. Sustainability 2010, 2, 2499-2522. [CrossRef]

62. Smit, J.; Nasr, J.; Ratta, A. Urban Agriculture: Food, Jobs and Sustainable Cities; United Nations Development Programme: New York, NY, USA, 1996; Volume 2, pp. 35-37.

63. Lohrberg, F.; Lička, L.; Scazzosi, L.; Timpe, A. Urban Agriculture Europe; Jovis: Berlin, Germany, 2016.

64. Kou, H.; Zhang, S.; Liu, Y. Community-Engaged Research for the Promotion of Healthy Urban Environments: A Case Study of Community Garden Initiative in Shanghai, China. Int. J. Environ. Res. Public Health 2019, 16, 4145. [CrossRef]

65. Fei, L. Humanized Design on Residential Community Garden: Taking Beijing Langqinyuan Community for Example. J. Beijing For. Univ. Soc. Sci. 2013, 1, 10. 
66. Li, X.; Hui, E.C.; Chen, T.; Lang, W.; Guo, Y. From Habitat III to the new urbanization agenda in China: Seeing through the practices of the "three old renewals" in Guangzhou. Land Use Policy 2019, 81, 513-522. [CrossRef]

67. Xuan, X. Research on Participatory Community Environmental Renewal-Taking Guangzhou Yanyunxi Community Micro-Transformation Workshop as an Example. J. Human Settl. West China 2018, 4, 5.

68. Cai, Y.; Yang, X.; Li, D. "Micro-transformation": The Renewal Method of Old Urban Community. Urban Dev. Studies 2017, 4, 5.

69. Dowall, D.E. Urban residential redevelopment in the People's Republic of China. Urban Studies 1994, 31, 1497-1516. [CrossRef]

70. Dooley, C.M. Multicultural literacy teacher education: Seeking micro-transformations. Lit. Res. Instr. 2008, 47, 55-75. [CrossRef]

71. Shuo, Q.; Qing, Z. Inclusive Development Environment Micro-Transformation of Traditional Scene Community, Guangzhou. Planners 2017, 9, 4.

72. Zhou, Y.; Deng, T.; Gan, H.; Zhao, Y.; Tang, X. Study on the Aging Transformation of Old Residential Areas. In Proceedings of the 4th International Conference on Modern Management, Education Technology and Social Science (MMETSS 2019), Dalian, China, 20-22 September 2019.

73. Chen, J.-W.; Lian, D.-X.; Zhao, X.-M. Micro-transformation Strategy of Pedestrian Green Space in Guangzhou High-density Old Residential Area. Guangdong Landsc. Archit. 2018, 6, 9.

74. Li, X.; Han, S.S.; Wu, H. Urban consolidation, power relations, and dilapidated residential redevelopment in Mutoulong, Shenzhen, China. Urban Studies 2019, 56, 2802-2819. [CrossRef]

75. Li, B.; Liu, C. Emerging selective regimes in a fragmented authoritarian environment: The 'three old redevelopment' policy in Guangzhou, China from 2009 to 2014. Urban Studies 2018, 55, 1400-1419. [CrossRef]

76. Ceng, D.; Wu, J.; Huang, H.; Zhou, M. Exploration on “Micro-Transformation" of Old Factory in Guangzhou Based on Institutional Design: A Case Study of International Unit Creative Park. Shanghai Urban Plan. Rev. 2017, 5, 45-50.

77. Ning, Y.; Ji, Q.; Sun, S.; Wang, C. Xi'an Old Town Renewal Model and Method. Planners 2016, $12,8$.

78. Cattaneo, T.; Giorgi, E.; Ni, M. Landscape, architecture and environmental regeneration: A research by design approach for inclusive tourism in a rural village in China. Sustainability 2019, 11, 128. [CrossRef]

79. Li, X.; Zhang, F.; Hui, E.C.-m.; Lang, W. Collaborative workshop and community participation: A new approach to urban regeneration in China. Cities 2020, 102, 102743. [CrossRef]

80. Du, Y. Community Governance in Chinese Context: Empowerment and Enrichment. Public Adm. Policy Rev. 2018, 1, 4 .

81. Ma, M.; Tao, S. Co-Governance and Sharing: The Exploration and Path Research of Social Organizations Participating in Urban Community Governance in Kunming. In Proceedings of the 5th International Symposium on Social Science (ISSS 2019), Xi'an, China, 15-16 December 2019; pp. 414-422.

82. Zhang, X.; Kuchinke, L.; Woud, M.L.; Velten, J.; Margraf, J. Survey method matters: Online/offline questionnaires and face-to-face or telephone interviews differ. Comput. Hum. Behav. 2017, 71, 172-180. [CrossRef]

83. Liu, Y.; Fan, H.; Wei, M.; Yin, K.; Yan, J. From edible landscape to vital communities: Clover nature school community gardens in Shanghai. Lands. Archit. Front. 2017, 5, 72-84. [CrossRef]

84. Zhou, C.; Zhou, Z.; Xiong, H.; Wang, W. Construction of children's community garden based on urban agriculture: Taking the kid's garden in the campus of hunan agricultural university for an example. J. Urban Stud. 2017, 6, 69-73.

(C) 2020 by the authors. Licensee MDPI, Basel, Switzerland. This article is an open access article distributed under the terms and conditions of the Creative Commons Attribution (CC BY) license (http://creativecommons.org/licenses/by/4.0/). 